\title{
The Moral Duty to Love One's Stakeholders
}

\author{
Muel Kaptein ${ }^{1} \mathbb{D}$
}

Received: 24 June 2020 / Accepted: 13 July 2021 / Published online: 20 July 2021

(c) The Author(s) 2021

\begin{abstract}
Much has been written about the general moral duty to love one's neighbors. In this article, I explore the specific application of this moral duty in the work setting. I argue from a secular perspective that individuals have the moral duty to love their stakeholders. Loving one's stakeholders is an affective valuing of the stake-related values these stakeholders pursue and as such is the real recognition of one's stakeholders as stakeholders and of oneself as a stakeholder of one's stakeholders. This moral concept of stakeholder love offers promising contributions to stakeholder theory, leadership theories, and ethical theories in general and business ethics theories in particular.
\end{abstract}

Keywords Love $\cdot$ Neighborly love $\cdot$ Moral duty $\cdot$ Stakeholder love

\section{Introduction}

To love one's neighbors is a moral duty in many religious traditions. Jewish, Christian, Islamic, Buddhist, and Hindu traditions all stress the moral duty to love one's neighbors (Neusner \& Chilton, 2005; Ruhe \& Lee, 2008; Templeton, 1999). The Christian bible states that one should love one's neighbor even if the neighbor is a stranger or enemy and that loving one's neighbor is one of the most important commandments (Deuteronomy 10:19; Matthew 22:37-39). Many religious scholars have defended and operationalized the duty of neighborly love (e.g., Aquinas, 1485; Augustine of Hippo 400; Barth, 1936; Kierkegaard, 1847; Luther, 1520). The central term for this neighborly love is agape, where love is an affection that is unconditionally directed to the other person, thus making it different from sexual love, brotherly love, familial love, self-love, or love for things and ideals (Hanley, 2017; Lee, 1977; Lewis, 1960; Nygren, 1930; Sternberg, 1986).

As neighborly love is important in religious traditions, is there then, from a secular perspective, a similar duty in the work setting? In other words, does every worker have the duty to love their neighbors? A secular perspective is important because the outcomes of its deliberations aim to

Muel Kaptein

mkaptein@rsm.nl

1 RSM Erasmus University Rotterdam, Room T11-53, P.O.

Box 1730, 3000 DR Rotterdam, The Netherlands have universal applicability rather than a restricted or narrow one that only applies to those who subscribe to the religion. The work setting is important because work, in terms of one's job and labor, is a substantial part of society's functioning and the lives of most human beings (Applebaum, 1992; Strangleman \& Warren, 2008). Such a moral duty of neighborly love would have implications for what could be expected of workers: how would organizations address or express this duty in their codes of conduct, for instance? The adoption of this duty by workers could also have positive implications for themselves and their neighbors. Research already shows that certain types of neighborly love relate to higher level of satisfaction of workers, more trust among workers, better behavior towards others, and improved wellbeing of others (Barsade \& O'Neill, 2014). However, these positive outcomes cannot be used to ground the moral duty of neighborly love because grounding a duty concerns deontological ethics instead of consequentialist ethics (Kaptein \& Wempe, 2002). Neither does the grounding of the moral duty of neighborly love concern virtue ethics because the virtue or disposition of neighborly love differs essentially from the duty or the moral obligation of neighborly love (Frankena 1973; Kaptein \& Wempe, 2002).

This article establishes that there is a secular moral duty of neighborly love in one's work by first examining whether there is a secular approach that sufficiently grounds a moral duty to love either one's neighbors in general or one's neighbors in the context of one's work. An approach that sufficiently grounds a moral duty to love one's neighbors in 
general can be used to examine whether and how this moral duty is applicable to the work setting. In the philosophical and normative ethics literature, I found nine approaches that either defend or refute a general moral duty of neighborly love. In my analysis, none of these approaches could sufficiently justify or refute such a moral duty. Therefore, I look at the work and organizational literature for various theories that try to establish a moral duty of neighborly love in the work setting specifically. Some of these accounts ground this specific moral duty by attaching neighborly love to another moral concept. As I will show below, these accounts also turn out to be problematic. This literature review and the analysis of the relevant approaches comprise the first part of the article.

The second part of the article presents my argument for the moral duty of neighborly love in one's work. Neighborly love is understood as an affection that is unconditionally directed to fellow human beings who can be considered as one's figurative neighbors. This is my working definition of neighborly love, and I argue that this type of emotion can be understood in the work setting as stakeholder love (the "what" and "who"). The concept of stakeholder love I develop grounds the moral duty of neighborly love in one's work (the "why"). In the context of one's work, one's stakeholders are, at the very least, one's neighbors, and loving one's stakeholders is an affective valuing of the stake-related values one's stakeholders pursue and, as such, is the real recognition of one's stakeholders as stakeholders and of oneself as a stakeholder of one's stakeholders. The stakeholder approach to neighborly love provides the middle ground to limit this duty in the sense that it circumscribes to whom the duty is owed: not everyone and not only oneself, and only when a stakeholder is a stakeholder. The article ends with a discussion of some potential misinterpretations of the developed concept of stakeholder love, the concept's promising contributions to various theories (stakeholder theory, leadership theories, ethical theories in general, and to business ethics theories in particular), some of the possible directions for future research, and the practical implications for organizations and for people in their work.

\section{Literature on the Moral Duty of Neighborly Love in General}

To be able to ground a moral duty of neighborly love in the work setting, we first have to examine whether there is a normative approach that sufficiently grounds the moral duty of neighborly love in general. At least nine such approaches can be distinguished in the philosophical and ethical literature. Although these approaches provide useful considerations for establishing whether there is a moral duty of neighborly love, I conclude that they do not provide sufficient ground for either accepting or rejecting the moral duty to love one's neighbors in general. I start with Kant's approach of neighborly love because he is considered a prominent philosopher who provides a justification for the aforementioned moral duty (Hanley, 2017).

The practical neighborly love approach. Kant (1797) has paid considerable attention to the subject of neighborly love and his work has been much studied (Hanley, 2017; Horn, 2008; La Caze, 2005; Rinne, 2018; Schönecker 2010; Wennemann, 1998). Kant defines neighborly love or love of mankind as an affective readiness to benign actions to promote the happiness of others. For Kant, this love is high and noble, and a loving world is the ideal ethical community. He considers his own moral philosophy as fundamentally in accord with the Christian neighborly love; or at least, this is what he wishes (Horn, 2008). However, Kant argues that neighborly love as an inclination cannot be commanded and is even an absurdity: "Love is a matter of feeling, not of willing, and I cannot love because I will to, still less because I ought to (I cannot be constrained to love)." (1797; 6:401). Love as feeling cannot be commanded because then it is no longer love: we do not really love the person because we love for the sake of duty and not for the sake of the person themself.

However, Kant does not reject the duty of neighborly love. He argues that there is a moral duty of practical love, which he defines in terms of benevolence or doing good to others. The maxim of practical love is a universal duty because it satisfies the universalizability test of a categorical imperative: if people want to be practically loved by others, they ought to practically love others. This duty, which arrests one's self-love, is unrelated to whether people find others worthy of love, and Kant argues, it is best understood as proper self-love extended by reason. By displaying this practical love, individuals then cultivate their love of mankind. The ground that Kant provides for the moral duty of neighborly love has its price. In justifying neighborly love, Kant has sacrificed what he himself defines as the essence of love, a point that Hanley (2017) also signals. Kant's proposed duty of practical love is about benevolence, which is behavior, and not about feelings preceding behavior which are, as Kant defines them too, the essence of love. To safeguard the essence of neighborly love, other philosophers have tried other approaches to morally ground neighborly love in other ways. Hanley (2017) gives a detailed overview of some of these approaches.

The approach that focuses on a different concept than neighborly love. Hanley (2017) shows that during the Age of Enlightenment, philosophers searched for concepts other than agape to save the notions of other-directedness and feelings or sentiments. For example, Adam Smith focused on sympathy, David Hume on humanity, and Jean Jacques Rousseau on pity. Other concepts that have been proposed in 
this respect are charity and justice by Leibniz (1693), generosity by Descartes (1649), compassion by Schopenhauer (1840), care by Heidegger (1927), and solidarity by Arendt (1963). Although each of these concepts can have its own, even rich, value, any concept other than love loses at least something of the meaning of love because it is, as such, not love (Hanley, 2017).

The approach that appeals to neighborly love. The appeal-to-love approach aims to soften the duty to love by turning it into an appeal to love. A duty, as an obligation for everyone, can be far-reaching and demanding. Some philosophers have, therefore, taken a more cautious approach. Nussbaum (2013: 3) praises other-directed love because this love is the best means of "getting people to think larger thoughts and recommit themselves to a larger common good." Nussbaum argues that love mitigates the self-centeredness that defines today's world and the forces of radical evil that is in every human being. Nussbaum calls for a politics of love and the transformation of the human heart. However, she does not claim that human beings should love one another. Others who make a similar general appeal to love are Hardt and Negri (2004), who call for love to serve as the basis for the construction of a new society; Kaufmann (2011), who views today's great psychological poverty of selfish individualism and instrumental, cold, and calculating reason caused by the lack of love as political principle; and Badiou (2012), who proposes love as possible point of resistance against the obscenity of the market. Although these appeals may be persuasive, they do not yet provide any argument that each person has a moral duty to love their neighbors; they are "only" a general call to do so.

The approach that limits the domain of neighborly love. Another approach for grounding the moral duty of neighborly love is to limit the domain to which the duty applies. The advantage of this, what I call, domain approach is that the moral duty might be easier to justify or refute because it is only about love within certain spheres. Some of the domains within which the duty is circumscribed are marriage, family, school, and government. For example, Solheim (1999) explores whether parents have a duty to love their children and concludes that there is only a duty to try to love because love as emotion is partly outside of what people can influence, but people can develop those character traits, such as sensitivity, that stimulate their love. Although this domain approach can yield relevant results for establishing whether there is a moral duty of neighborly love in a certain domain, these results are not directly applicable to other domains that may have different characteristics that are relevant for determining whether there is a moral duty to love one's neighbors. For example, children are not just neighbors; they have a specific, intense, and vulnerable relationship with their parents (cf. Majerhold, 2020). Therefore, relationships with one's figurative neighbors cannot be the same as those between parents and their children. So far, there is no domain approach that claims that its results are generalizable to all domains of life or, for our purposes, to at least the domain of work.

The approach that focuses on the right of neighbors to be loved. Another approach is to focus not on the duty to love but on the right to be loved. Some philosophers argue that although neighborly love is essential there is no ground for the duty to love one's neighbors. To rescue neighborly love as an ethical notion, they focus instead on the right to be loved. For example, Liao $(2012,2015)$, who limits his study to the domain of family, focuses on the right of children to be loved instead of on the duty of parents to love their children. For Liao, children have a right to be loved because as human beings they have a right to those conditions that are primarily essential for a good life and being loved is such a condition for them. In Ferracioli's (2014) case, she does not argue for the duty of parents to love their children but for the state's duty as a third party to ensure that children are loved. Although putting the attention on other subjects can be original and useful, this does not sufficiently ground the duty to love one's neighbor because it only provides arguments for the corresponding obligations or rights of others.

The approach that supports the idea that neighborly love can be commanded. As mentioned above, Kant claims that love cannot be commanded because it is a feeling, an emotion. Taylor (1970) and Cowden (2012a, 2012b) support this position. A counter argument to this Kantian view is the claim that love is not an emotion but an attitude. Raz (1994) argues that love involves attitudes like promoting another person's well-being for the person's sake and wanting to be with the person. Approaching love as an attitude opens the door to the view that love can be internally controlled and as such can be externally commanded and be the object of morality. Liao (2006) objects to the love-is-an-attitude approach by arguing that love involves affection and thus love cannot be without emotions. To rescue the moral duty of neighborly love, Liao argues that emotions nevertheless can be controlled and commanded because "we can bring about a particular emotion with success by giving ourselves reasons to have particular emotions" (p. 4). However, Liao does not provide an argument as to why love is a duty. In this sense, Liao's work does not provide the necessary grounding for the moral duty to love one's neighbors.

The approach that focuses on the duties neighborly love entails. Another approach is to focus not on the duty to love but on the duties that the presence of love entails. For example, Velleman (1999) argues that love is a moral emotion because it is an "arresting awareness of value" by the lover in their beloved; and Frankfurt (1998, 1999, p. 23) argues that the imperatives of love carry duties: "Love is itself, for the lover, a source of reasons." Others who use this approach are Voice (2011), who argues that love has authority because 
it is a sentimental contract between the lovers; Wallace (2012), who explores the obligations of a loving relationship; and Ferry (2013), who explores the implications of the ascendance of love as the central value in modern societies (meaning, the focus is on those we love most: the future generations). The duties resulting from love can be relevant in determining what the duty to love is; for example, that the more duties love entails, the more demanding it is and thus the stronger are the arguments for the duty to love. However, this approach does not in itself provide any ground for the moral duty to love one's neighbor.

The neighborly-love-is-a-virtue approach. Another approach is to propose that love is a virtue instead of a duty. Frankena (1973) holds that the basic form of an ethics of love is "Be loving!" He proposes an ethics of love conceived as an ethics of virtue (of being) rather than as an ethics of duty (of doing). For Frankena, the idea of virtue is more attractive than the idea of duty because love is a disposition and should not be a pattern of actions (the latter would make love deontological). Frankena does not claim that everyone should develop the disposition of love, nor does he claim that there is no moral duty to love one's neighbor. He only claims that a virtue approach is more attractive than a deontological approach to neighborly love. A virtue approach in this case is useful in that it helps to explore the moral relevance of neighborly love. However, the virtue approach as developed by Frankena does not offer any justification for why neighborly love is not a moral duty. Therefore, we cannot use Frankena's approach to either ground or refute the moral duty of neighborly love.

The approach that tries to altogether dismiss the moral duty of neighborly love. Next to approaches that have tried to defend the duty of neighborly love (or parts of it) are attempts to dismiss or object to this moral duty altogether. There are philosophers who argue that self-love is more important than other-regarding love. For example, Hobbes (1651) promotes self-love as the object of all moral actions. Mandeville, as interpreted by Bragues (2005), posits that self-love can include love for others only if the latter is motivated by the immediate pleasure of contributing to one's own happiness. Others have argued that the duty of neighborly love threatens the love for those who deserve it most. According to Mackie (1990, pp. 130-131), a universal and equal concern for all men is an ethics of fantasy: "People simply are not going to put the interests of all their 'neighbours' on an equal footing with their own interests and specific purposes and with the interests of those who are literally near to them." Baron (1986) and Wolf (1992) also discuss this idea that love (being partial) and morality (being impartial) conflict. For Freud (1930), who was not a philosopher by profession but developed strong moral arguments about neighborly love, the duty to love one's neighbors is unreasonable, unjust, and self-defeating because it means giving love that ought to be reserved for insiders to outsiders. Freud claims that one cannot love someone as much if one ought to love everyone; that's why the duty also leads to an unsatisfiable sense of guilt because it is impossible to fulfil. Singer (2009, p. 304) objects to this Freudian claim by arguing that people do not need to have equal quantities of identical love: "Loving a stranger does not mean treating him as a member of one's family." Annas (1984) and Kapur (1991) argue that love, if properly conceived, is compatible with morality. Since the approach that tries to refute the moral duty of neighborly love has not provided convincing arguments, we can continue our search for arguments that this moral duty exists.

As shown by the above review, there are various approaches for grounding or refuting the moral duty of neighborly love and so are their outcomes. This is not problematic and alarming as such because neighborly love is an important concept (Fromm, 1956; Reis \& Aron, 2008) and a complex one (Rinne, 2018; Zeiher \& McGowan, 2017). The review also shows that none of the approaches provides sufficient ground for accepting or rejecting the moral duty to love one's neighbor in general. Therefore, although these approaches provide useful elements for our endeavor to establish a moral duty to love one's neighbors in one's work, we cannot simply use the outcomes of one or more of these approaches and apply them directly to the work setting. In the next section, I examine whether there is an approach in the domain of work that can sufficiently ground the acceptance or rejection of the moral duty to love one's neighbors in one's work. I conclude that I could not find such approach in the current work and organizational literature. In the sections following the next, I develop my own arguments for the moral duty of neighborly love in the work domain.

\section{Literature on the Moral Duty of Neighborly Love in Work}

Neighborly love has received attention in the work and organizational literature and has been discussed next to other types of love, such as workplace romance (Boyd, 2010), brand love (Fournier, 1998), love of money (Tang et al., 2008), product love (Brough \& Isaac, 2012), work love (Kidder, 2006), and company love (Agarwal et al., 2018). The attention to neighborly love has been explicit (i.e., the term neighbor love or agape is used), via other types of love (such as companionate and compassionate love), or via related terms (such as passion, care, prosocial behavior, charity, and altruism). There have been descriptive studies that attempt to show the existence of neighborly love in the work setting (e.g., Barsade \& O’Neill, 2014, 2016; Graber \& Mitcham, 2008; Kuhn, 1992; Longenecker, 2013) and instrumental or positive studies on the antecedents and outcomes 
of neighborly love in the work setting (e.g., Agle et al., 1999; Barsade \& O'Neill, 2014; Blatt, 2009; O'Neill \& Rothbard, 2017; Tasselli, 2019). In the work and organizational literature, normative studies of neighborly love are often based on a religions perspective; for instance, the application of Augustine's, Aquinas', or Luther's concept of love in the work setting (e.g., Childs, 1997; Das Neves \& Melé, 2013; Natoli, 2008), or the application of the Catholic social tradition (e.g., Cima \& Schubeck, 2001; Sandelands, 2009, 2017), especially the encyclical letter "The Truth in Love" (e.g., McCann, 2011; Melé \& Naughton, 2011; Yuengert, 2011). Next to the religious perspective, a broader spiritual perspective is used in the work and organizational literature to explain the importance of other-directed love in the work context (e.g., Fry, 2003; Karakas, 2010; Rothausen, 2017). However, none of the above-mentioned descriptive, instrumental, and religion-based literature provide normative and secular ground for the moral duty of neighborly love in the work setting.

There are a number of secular attempts to morally ground neighborly love in the work setting by linking neighborly love to another moral concept. Kouzes and Posner (1992) argue that love constitutes the soul of ethical leadership, and Caldwell and Dixon (2010) argue that love is one of the critical values of the modern leader. Okpala and Caldwell (2019) see love as part of the heart of ethical stewardship, while Van Dierendonck and Patterson (2015) claim that compassionate love is a cornerstone of servant leadership. A weakness of the above-mentioned approaches is that they justify the importance of love by attaching it to another moral concept, such as ethical leadership, stewardship, and service. As long as this other moral concept is not irrefutably shown to be morally required in people's work, then we cannot use these approaches as such to ground the moral duty of neighborly love in the work setting. The same holds for other concepts of which other-directed love is a part: e.g., care (Elley-Brown \& Pringle, 2021), humanism (Acevedo, 2012), personalism (Melé, 2009), compassion (Cignacco, 2019), and trust (Mayer et al., 1995).

There has been some debate about the applicability of neighborly love in the work setting. De George (1986) expresses reservations about including the concept of neighborly love in business ethics: the concept does not generate general rules on how it is to be applied to business ethics and therefore it is more puzzling than enlightening. Williams (1986) challenges De George's position by arguing that a narrative understanding of neighborly love can help clarify what constitutes a good life in the context of business. However, Williams does not say whether neighborly love is a moral duty. The different views of De George and Williams have not been taken up by other organizational scholars to explore whether there is a moral duty of neighborly love in the work setting. Koehn (1998) and Cooley
(2002) come close when they inquire whether businesses should be friends with their stakeholders. However, this is not the type of love (i.e., reciprocal) that corresponds with my working definition of neighborly love (i.e., unconditionally other-directed).

Instead of a duty-based approach to love, some scholars argue that in the context of work, other-directed love is a virtue. Solomon (1998) indirectly addresses elements of neighborly love when he operationalizes Adam Smith's idea of sympathy into two core virtues of the corporation: care and compassion. Solomon defines care as taking the interests of others as one's own and compassion as felt concern for another who is in some serious condition. A weakness of Solomon's approach is that the importance of care and compassion is dependent on another moral concept. Harris (2002) more explicitly addresses the concept of love by arguing that other-directed love is a management virtue; however, he concludes that his arguments do not provide a complete proof of love as a management virtue. Another virtue-based attempt is Argandoña's (2011): love is a virtue that people in business organizations should exercise in all their social relationships because people have transcendent motives, i.e., the desire to bring about in all their decisions a certain outcome in others. One weakness of this approach is that it assumes that all people have transcendent motives in all their decisions, but Argandoña does not provide any evidence for this. Another more important weakness is that he and other virtue proponents do not sufficiently ground the claim that neighborly love in the setting of work is not or cannot be a moral duty.

Based on the above review, we can conclude that the organizational and work literature does not provide sufficient justification for accepting or rejecting the moral duty to love one's neighbor in the work setting. When neighborly love is studied from a normative perspective, this is often based on a religious and spiritual perspective. When neighborly love is studied from a secular normative perspective, the concept is made dependent on another moral concept, it is proposed as a virtue but not refuted as a moral duty, or its applicability is only superficially discussed. In the next part of this article, I develop my approach for grounding a moral duty of neighborly love in the work setting. I provide a justification that is both secular and independent of other normative concepts.

\section{The Concept of Stakeholder Love as Neighborly Love}

To establish that there is a moral duty to love one's neighbors in the work setting, I first define my understanding of this specific concept of neighborly love. How we understand this concept determines whether and how we can ground its corresponding moral duty. My approach contains three 
understandings of neighborly love in the work setting. Each of these understandings is a middle ground for how this concept could be viewed. This middle-ground approach helps us define neighborly love not too ambitiously or idealistically, but realistically and without throwing away its essence. This approach views neighborly love in the work setting as love that is between loving everyone and only oneself (which is loving one's stakeholders), between self-sacrificing love and reciprocal love (which is love for the stakeholder and independent from one's own stakes), and between an overwhelming emotion and behavioral manifestations (which is a reason-based stakeholder love).

Loving one's stakeholders. The first middle ground is between loving everyone and loving only oneself. As mentioned above, so far there has been no serious secular attempt to ground the duty to love one's neighbor in the work setting. One possible reason for this is that the concept of neighbor is understood to mean "every other human being." For example, Kant (1797) talked about mankind, and Freud (1930) about outsiders and strangers. But as both noted, expecting that one should love everyone is maybe too demanding or, according to Mackie (1990), a fantasy. Fortunately, a distinctive feature of the term "neighbor" is that it does not necessarily mean "every other human being." If the latter should be the meaning, then we should not talk about neighbors but directly about everyone or humankind. The term "neighbor" contains in itself the limitation about whom should be loved. Neighbors are the people who are nearby, who are next to someone, who live in one's surrounding (Hanley, 2017).

The term "stakeholder" lends itself well to refer to one's neighbors in one's work. Following Freeman's (1984) classic definition, stakeholders are those people who can affect or are affected by an organization. Stakeholders are, figuratively speaking, the neighbors in one's work, those people who can affect or are affected by one's decisions (Jones \& Wicks, 1999) in one's work, i.e., in one's position, task, or function. Stakeholders are people both outside (e.g., clients) and inside the organization (e.g., coworkers). With respect to the duty of love, whether stakeholders other than individual human beings can be included as object of love, for instance groups, organizations, animals, and the natural environment, is outside of the scope of this article. I propose this topic as a future research direction.

We can further limit the stakeholders to be loved (i.e., the object of the duty) to only those who are affected, in the sense of being dependent on and influenced, by one's decisions. Excluded from this group are what Phillips calls (2003) derivative stakeholders, those who can only affect the organization: they are neither dependent nor influenced by one's decisions. Loving such stakeholders has no relevance for them; otherwise, they would also belong to the group of stakeholders who are affected by one's decisions. By limiting the group to be loved to those stakeholders who are affected by one's decisions, we lower the bar for establishing a moral duty to love one's neighbor. A narrow conception of whom to love makes the duty to love less demanding. In addition, because one's stakeholders are those who are dependent on one's decisions, we do not exclude any other relevant people whose interest is at stake. However, the relevant concept of stakeholder is broader than that of a shareholder or any other specific stakeholder, including one's own stakes (cf. Mitchel et al., 1997) and is consistent with the term "neighbors" because it does not encompass the subject themself and does not refer only to a part or specific group of neighbors.

Love for the stakeholder independent from one's own stakes. A second middle ground is between love as always self-sacrificing and love as always reciprocal. On the one hand, the concept of stakeholder love should retain the basic idea of neighborly love as agape, that is, love is not for the benefit of the loving subject. Neighborly love is disinterested (Whiting, 1991) in the sense that it is not primarily about the interests of the loving subject. Stakeholder love is love for the sake of the stakeholder; it is stakeholder-directed. It is, like neighborly love, unconditional in the sense that it does not depend on qualifications other than that a stakeholder (neighbor) is a stakeholder (neighbor). On the other hand, we do not need the idea of stakeholder love as being always self-sacrificing. Neighborly love is sometimes defined in terms of selflessness, self-denial, charity, altruism, and philanthropy (cf. Fehr et al., 2008; Hendrick \& Hendrick, 1992; Lewis, 1960; Post et al., 2002). This idea of love as selfsacrifice is not essential for the notion of neighborly love (Hanley, 2017; Oord, 2010) and neither, therefore, for our concept of stakeholder love. In the literature, it is argued that true love can be pleasant and profitable for the one who loves (Argandoña, 2011; Hanley, 2017). For example, Kant claims that practical love will reap an emotional reward for the lover, such as heightened esteem for, contentment with, and pleasure in oneself (Dierksmeier, 2013). Requiring stakeholder love to be only self-sacrificing without any benefit for the lover would make it more demanding and difficult, even impossible, to prove (i.e., demonstrate that there is no benefit at all for the lover). Therefore, I use a more realistic concept of love: stakeholder love that is directed to and based on the stakeholder themself, without excluding the possibility that this love benefits the loving subject (and/or their organization). These benefits are a result of stakeholder love and not the reason for it. In other words, stakeholder love is love for the stakeholder, being independent of the stakes of the lover.

Reason-based stakeholder love. A third middle ground is between love as an overwhelming emotion and love as behavioral manifestations. On the one hand, feelings are central to the concept of love, as Kant (1797) states for instance. However, these feelings should not be like the emotions of being in love with someone for the first time, which is a 
desperate and overwhelming feeling (Voice, 2011). This is not the kind of love we are looking for. When one has many stakeholders to deal with in one's work, it should be possible to love them all during the time that they are one's stakeholders. On the other hand, we should not move away from the idea of love as a feeling by defining love in terms of its manifestations. Kant's concept of practical love aims to make love practical, but it sacrifices a basic idea of neighborly love, that of love as a feeling. Also, definitions of love that include manifestations of love are not about love itself. For example, Underwood (2008) defines compassionate love in terms of giving the other a free choice, among other things. That love provokes many kinds of behavior does not make it equal to that behavior (Cavanaugh et al., 2015). The richness of the concept of love cannot be captured in its manifestations because love is about the intentions and considerations underlying and preceding these manifestations. Therefore, an approach to stakeholder love should not define love in terms of overwhelming emotions or behavioral manifestations. A reason-based approach to stakeholder love is a middle ground in this respect. Reasons ground emotions and precede behavioral manifestations. A reason-based concept of love, as argued by Moore (2018), means that love is based on the lover's motivating reasons instead of on their unexplainable emotions. A reason-based concept of stakeholder love then means that stakeholder love is at least based on the motivating reasons of the loving subject. As such, stakeholder love is not about the behavioral manifestations or the consequences of love. In the next section, this reason-based concept (third middle ground) of love for (second middle ground) the stakeholder (first middle ground) is used to ground the moral duty to love the stakeholders in one's work.

\section{The Moral Duty to Love One's Stakeholders in One's Work}

There is a ground for the moral duty to love the stakeholders in one's work: Loving one's stakeholders is an affective valuing of the stake-related values these stakeholders pursue and as such, it is the only real recognition of the existence of these stakeholders as stakeholders and of oneself as a stakeholder of one's stakeholders. This ground can be explained in four parts.

First, stakeholder love involves an affective valuation. Singer (2009), who analyzed the history of studying the concept of love, defines love as valuing. He distinguishes between appraisal love, which involves valuing a person based on that person's characteristic that is of value to the lover, and bestowal love, which involves giving a person value based on the lover's love for that person. This element of valuing is also adopted by Martin (1993), Underwood
(2008), and Helm (2017), while others use similar terms like appreciation (Fry, 2003), positive evaluation (Carroll \& Ahuvia, 2006), and affirmation (Vacek, 1994). However, in my approach, stakeholder love is not only about valuing. Love is a feeling of valuing, as Ferris (1988) states. This feeling is an emotion (Barsade \& O'Neill, 2014) and even an affection (Cavanaugh et al., 2015; Hanley, 2017; Whiting, 1991). It is an affection in the sense that the valuing is active (Fromm, 1956), true (Fromm, 1956), genuine (Van Dierendonck \& Patterson, 2015), and warm (Barsade \& O'Neill, 2014; Liao, 2006). Figuratively speaking, the valuing is done by one's heart (Klein, 2002; Kouzes \& Posner, 1992; Velleman, 1999) and even wholeheartedly (Clough, 2006). The term "affective valuing" resonates well with the term "affective trust," which is trust from the heart (Chua et al., 2008). In this sense, stakeholder love is opposed to stakeholder hate and stakeholder apathy or indifference.

Second, stakeholder love is based on the stake-related values that one's stakeholders pursue. Love as affective valuation should have an object. "Love is a way of valuing something" (Singer, 2009, p. 3). In my concept of stakeholder love, the stakeholders who are affected by one's decisions are the objects of love. Stakeholder love is stakeholderdirected. The object of love is not the same as the grounds of love, as Delaney (1996) claims. Love for a stakeholder should be based on what makes the stakeholder loveable in themself and not on what their value is for the lover (then it is not neighborly love). Stakeholder love is about loving the person for the person's sake (Martin, 1993), valuing the other for themself (Solheim, 1999), valuing the other at a fundamental level (Underwood, 2008), and showing appreciation for the value of others by loving them (Velleman, 1999). The values that a stakeholder pursues ground stakeholder love. Stakeholders are holders of stakes because they have a legitimate claim or interest in one's decisions (Phillips, 2003). For example, a customer wants a safe product and an investor, a good return. Each one is a stakeholder of the worker who can affect these interests, for example, by delivering a safe product or a good return. These stakes or interests are related to the values stakeholders pursue, such as health (in the case of the customer) and prosperity (in the case of the investor). By buying, investing, working, selling, cooperating, and living, stakeholders aim to achieve and safeguard what is of value for them (Kaptein \& Wempe, 2002).

The values stakeholders pursue form the ground for stakeholder love defined as valuing because others can value these values. This reasoning implies that stakeholder love does not require loving one's stakeholders based on their intrinsic value, which is what Jones and Wicks (1999) see as the normative ground for treating stakeholders as ends. The argument also does not imply that one should love stakeholders completely, but that the love should be value-based; or 
that one should love them based on all their values, but that stakeholders should be loved based on those values that are at stake and which one affects; or that one should only love those stakeholders who are in serious problems, which is the core element of compassionate love, but that one should also love those stakeholders who want to advance their own values. Thus, stakeholder love is grounded on the argument that one should love a stakeholder not because this stakeholder is a stakeholder (holder of interests) but because of the stakeholder's values that are at issue and that one affects.

Third, stakeholder love is the recognition of the existence of one's stakeholders as stakeholders and of oneself as a stakeholder of one's stakeholders. Loving a stakeholder is recognizing the stakeholder's existence because one affectively values the stake-related values of that stakeholder. By affectively valuing the relevant values of one's stakeholders, one attributes importance (value) to these values, thus making the stakeholder, the holder of these values, valuable for the one who loves. By making the stakeholder valuable, one recognizes that the stakeholder is not just someone whose values are at stake. More than this, one recognizes that this stakeholder is one's own stakeholder, who is dependent on one's decisions and as such has a stake in oneself and in one's decisions. So, stakeholder love is an affirmation, a confirmation or declaration (cf. Carroll \& Ahuvia, 2006) that the stakeholder exists, as a stakeholder, for the worker who loves that stakeholder. By loving a customer, the worker recognizes that this customer is not just an individual who buys products somewhere, but that this is their customer who has a stake, an interest, in their decisions. By loving a stakeholder, one also recognizes that one is relevant for the stakeholder because one affects the values the stakeholder pursues, and that consequently, one is a stakeholder of one's stakeholder. So loving stakeholders is not only recognizing those stakeholders but also recognizing oneself as a stakeholder of those stakeholders.

Fourth, stakeholder love is the only way to really recognize one's stakeholders. This final step in the argument is important to make stakeholder love a moral duty. As argued above, by loving a stakeholder one recognizes that the stakeholder exists for oneself. Loving a stakeholder is also the only way to really acknowledge their existence as a stakeholder because it is the only way to show that the stakeholder is valuable. Only by loving a stakeholder can one value the stakeholder and the values that the stakeholder holds. All other ways of engaging with stakeholders, like showing respect, closing contracts, doing investments, and lending a helping hand, can also or even be only motivated by one's own interests. It is only through stakeholder love can one show that one values the values of the stakeholder because they are valuable independent of the benefits they generate for oneself. This concept of stakeholder love implies that if one does not love one's affected stakeholder, then one does not recognize this stakeholder as one's stakeholder or that one is the stakeholder of that stakeholder. Therefore, when stakeholder love is the only way to really recognize one's stakeholders, one should love one's stakeholders because otherwise one denies that one has stakeholders, which implies that one cannot be a stakeholder. Ignoring the existence of one's stakeholders and oneself in a work setting with influential relationships and dependencies (Donaldson \& Preston, 1995), where individuals affect each other, is impossible and self-contradictory. Thus, the only way to recognize one's stakeholders and oneself as stakeholder is to love one's stakeholders, which makes this a moral duty.

\section{Discussion}

This article presented a ground for the moral duty to love one's stakeholders in the context of work: loving one's stakeholders is an affective valuing of the stake-related values these stakeholders pursue and as such is the only real recognition of the existence of one's stakeholders as stakeholders and of oneself as a stakeholder of the stakeholders. Loving one's stakeholders is a moral duty because there is no other way to really acknowledge the existence of one's stakeholders, and acknowledgment is necessary because it is impossible to ignore that they are stakeholders. To arrive at this conclusion, I developed a concept of love that is between loving everyone and only oneself (which is loving one's stakeholders), between love as always self-sacrificing and as always reciprocal (which is love for the stakeholder and independent from one's own stakes), and between love as an overwhelming emotion and as behavioral manifestations (which is a reason-based stakeholder love). In this section, I describe the theoretical contributions of the concept of a moral duty to love one's stakeholders followed by directions for research and implications for practice. But first, I describe potential misconceptions about the approach presented here for grounding a moral duty of stakeholder love.

\section{Potential Misinterpretations}

To minimize misinterpretations of the presented approach for grounding a moral duty of stakeholder love, it is important to discuss what this approach and its resulting moral duty actually do and do not imply.

The approach and the resulting moral duty do not suggest that stakeholder love is "all we need" and that "the world revolves around love." That stakeholder love is a moral duty does not in itself suggest that all other duties or virtues are redundant or that all other governing mechanisms, like contracts and monitoring, are unnecessary. The concept of the moral duty of stakeholder love also does not suggest that stakeholder love, even if it were the most important duty, 
could not conflict with other duties. Duties can conflict with each other, that is why there are ethical dilemmas (Kaptein \& Wempe, 2002), and such conflicts do not undermine the validity of these duties. The concept of stakeholder love does not suggest that there is love only when one promotes the interests of stakeholders. One can harm stakeholders and still love them, for example, when one must give moral priority to another stakeholder. However, such instances of harming should be accompanied by feelings of pain and shame (cf. Frankfurt, 1998; Levinas \& Robbins, 2001; Nozick, 1989). The concept of stakeholder love does not suggest that self-love and self-interest are unethical—stakeholder love is "only" disinterested from one's own interests-or that those who are not stakeholders do not have values or are nonexistent. Velleman (1999) argues that loving some and not others entails valuing them differently but does not entail attributing to them different values. This argument also applies to the concept of stakeholder love: nonstakeholders do not necessarily have different values, only that their values should be valued differently by those for whom they are the stakeholders.

There are many other things the approach presented here and its resulting moral duty do not suggest. The relevant concept of love used here does not suggest that a worker should love the values of stakeholders; rather, it holds that stakeholder love is based on the values of stakeholders. Neither does the concept of love suggest that a worker approves or should approve all the moral practices and values of their stakeholders. Even one's spiteful shareholder, aggressive customer, or narcistic coworker should be loved because what makes those stakeholders lovable are the values that make them a stakeholder, like economic prosperity, satisfaction, and employment. Furthermore, the relevant concept of love does not mean that a worker should know each stakeholder individually. One could also love a stakeholder one has never met. Finally, the moral duty of stakeholder love does not imply that it is forbidden to love nonstakeholders or to love those stakeholders that one cannot affect in one's work, or to love other human beings outside of one's work. Workers may also have a moral duty to love their neighbors in other settings. The presented approach only suggests that there is a moral duty of neighborly love in the work setting: i.e., to love one's stakeholders or those who are affected by one's decisions in one's work.

The presented concept of stakeholder love does not suggest that stakeholder love is always attainable or realizable. A possible objection against a moral duty of stakeholder love is that it is unrealistic and therefore cannot be a duty. A possible reply is to point to empirical studies that have shown the existence of love for certain stakeholders (e.g., Barsade \& O'Neill, 2014) and of stakeholders who love their organization (Dalman et al., 2019; Yim et al., 2008). However, this is a weak response because it would fall apart if it can be shown that love either does not exist or hardly does in practice. A stronger response is to argue that the justification of a moral duty is not determined by how easy it is to fulfill. The more unattainable and difficult to realize stakeholder love is, the more reason there is to make it a duty so that workers would at least attempt to as much as possible embed stakeholder love in their work (cf. Nussbaum, 2013). In addition, the less room there is in one's work for stakeholder love, the more stakeholder love speaks when it is nevertheless present (cf. Fromm, 1956). It is in what Zeiher (2017) calls the "struggle as love par excellence" that real love becomes apparent. For this reason, stakeholder love is an achievement, which is similar to what Fromm says about brotherly love: such love is not always automatically felt because otherwise a duty would be useless. The attempt to as much as possible embed stakeholder love also means that when loving stakeholders is difficult, workers should create the conditions that would make loving these stakeholders more possible. In this respect Liao (2006) discusses methods on how love can be cultivated, for example, by deliberately placing oneself in situations in which one knows one would probably experience particular emotions.

Understanding neighborly love as stakeholder love with its resulting moral duty does not suggest that stakeholder love is either love as appraisal or love as bestowal. Stakeholder love is a combination of both. Singer (2009) distinguishes these two views of love, Helm (2010) argues for an intermediate position, but Moore (2018) tries to reconcile both approaches. Whereas appraisal love is object centered and reason based (given that love is based on reasons derived from the valuable properties of the beloved) and bestowal love is subject centered and nonreason based (because love originates in the lover), Moore proposes a subject-centered, reason-based model of love: love arises within the lover and is based on the lover's motivating reasons. The concept of stakeholder love is consistent with Moore's model in the sense that stakeholder love arises within the person and is based on his motivating reasons. In our case, these motivating reasons derive from the stake-related values the stakeholders embody. By appraising the values of the stakeholder, one bestows value on the stakeholder and shows that the stakeholder is of value to oneself. The love for stakeholders is motivated by what makes them lovable, and this is then affirmed by loving them. Thus, stakeholder love is about discovering the relevant values of stakeholders and affectively valuing those values. On the one hand, stakeholders exist even when they are not loved; they are affected by one's decisions. However, the stakeholders become a reality for those whose stakeholders they become through stakeholder love.

The presented approach also implies several things that seem to be irrelevant for the moral duty to love one's stakeholders. One implication is that this moral duty does 
not depend on the extent to which the stakeholder values being loved. This is Liao's (2012) argument for children's right to be loved. Bridoux and Stoelhorst (2014) argue that stakeholders may have heterogeneous motives: there are reciprocal stakeholders who care about fairness (and where a fairness approach is more effective to create value), and there are also self-regarding stakeholders who do not care about fairness (and where an arm's length approach is more effective). My argument for the moral duty of stakeholder love does not use Bridoux and Stoelhorst's notion for two reasons: their notion is inconsistent with my view that the moral duty is independent of the needs of stakeholders (and thus my argument is not dependent on the empirical situation), and it supports the unacceptable conclusion that faking stakeholder love is morally acceptable if the stakeholders believe they are loved (cf. Liao, 2012, 2015). The presented view is that stakeholder love is a duty regardless of whether stakeholders value being loved as stakeholders. By the same token, the moral duty of stakeholder love is irrespective of whether the duty holder is loved back by the stakeholders.

The concept of stakeholder love implies that one should love all of one's stakeholders who are affected by one's decisions and not just a selection of them. However, the concept also suggests that stakeholder love is not infinite. When a person is no longer an affected stakeholder, the moral duty to love this person expires. In this sense, stakeholder love is conditional because it is only a moral duty if the stakeholder is one's stakeholder (this also holds for the general concept of neighborly love: it only applies to neighbors if they are one's neighbor). The concept of stakeholder love also means that hating one's stakeholders, which is the opposite of loving them, is immoral. The same holds for apathy or indifference toward one's stakeholders. Stakeholder love also implies that love for one's stakeholder can be learned and developed; otherwise, it would not be a moral duty. Frierson (2002) argues, based on his analysis of Descartes' work, that love can be learned, and Liao (2015) argues that love can be controlled and commanded. From the concept of stakeholder love follows that when one must deal with multiple stakeholders at the same time, one should love all these stakeholders at the same time, and even if one's transaction with a stakeholder is brief, one should love that stakeholder at that instance.

\section{Theoretical Contributions}

The concept of a moral duty of stakeholder love has promising contributions to stakeholder theory, (business) ethical theories, and leadership theories.

The concept of stakeholder love has some possibly important implications for stakeholder theory. In this article, stakeholder love is operationalized as affections people in their work should have for their stakeholders. The concept of stakeholder love is new. In the stakeholder literature, related concepts like care and compassion are applied but not love as such. Many other normative foundations of stakeholder theory have been proposed, e.g., property rights, principles of fair play, the common good, organizational justice, and pragmatism (Hosmer \& Kiewitz, 2005; Laplume et al., 2008). The concept of stakeholder love in this article is based on the concept of stakeholder itself and thus does not need another theory to justify it, like stewardship or feminism (Burton \& Dunn, 1996; Liedtka, 1996; Wicks et al., 1994). The concept of stakeholder love is, on the one hand, minimal in the sense that it does not give direction to what and how stakeholders should be dealt with, and on the other hand, it is maximal in the sense of that it refers to the heart of why stakeholders should be recognized and served. Thus, the concept of stakeholder love opens the door for a stakeholder theory of love, which may include not only a normative stream but also instrumental and descriptive ones. For now, the concept of stakeholder love meets the conditions set by Parmar et al. (2010): for stakeholder theory to be a theory, it should propose duties owed to stakeholders that are not the sort of duties owed to every person but are owed to them qua stakeholders.

The concept of stakeholder love offers promising contributions to the ethics literature in general. While there have been secular attempts to formulate a duty of neighborly love in general or in specific domains, there is as yet no undisputed outcome. Although it is not expected that this approach would remain unchallenged, the approach is new and may be fruitful for ethical theorizing in general. The concept of stakeholder proposed in this article does not imply that everyone should love everyone; it requires loving only those who depend on one's decisions. This makes the approach more realistic and personal, which makes is applicable, with utmost care, outside the work setting given that one's neighbors is not everyone in the world. In this way, the parable of the Good Samaritan used to show what neighborly love means (cf. Agosta, 2020) fits well in the concept of stakeholder love: the victim was not just someone who was in need but someone who, when the Samaritan saw him lying on the ground, became the Samaritan's stakeholder.

From a business ethics point of view, this article is, as far as I know, the first to develop a secular ground for the moral duty of neighborly love in the work setting, which is characterized as the moral duty to love one's stakeholders in one's work. When stakeholder love is a moral duty for everyone in their work, this means that business ethics should be concerned with the importance of this duty and how it relates to current theories in business ethics. Hegel (1820: §158) describes love as "ethical life in its natural form" and Fredrickson (2013) argues that love affects everything we feel, think, do, and become. If stakeholder love is as important as characterized by Hegel and Frederickson, 
then this concept would have a substantial impact on the field of business ethics.

The concept of stakeholder love can also possibly contribute to leadership theories. Scholars in the field of leadership have argued for introducing a concept of love. The normative approaches of love are usually based on some specific normative theory. For example, Van Dierendonck and Patterson (2015) argue for love as an element of servant leadership. As discussed above, love as an element of servant leadership does not make love a duty (for leaders) because the duty of love depends on whether, in this case, servant leadership is seen as a moral duty. In the presented approach, the moral duty of stakeholder love holds for every person in the work setting, therefore it also holds for leaders in the work setting. Furthermore, the scope of love is enlarged because love is operationalized to all stakeholders and not only to followers, usually employees, as Van Dierendonck and Patterson (2015) do. Therefore, leaders have the duty to love not only their employees but all the stakeholders who are affected by their decisions and to lead in such a way that their employees follow by loving their own stakeholders, too.

\section{Research Directions}

Besides the theoretical contributions and their associated directions for research, a moral duty of stakeholder love, as developed in this article, offers many other promising research directions.

One research direction is validating the proposed moral duty of stakeholder love. The main question is whether the arguments given here for the moral duty of stakeholder love are sound and robust. Given that this topic is novel and potentially far-reaching, this article opens the door for research on whether stakeholder love is indeed a moral duty for every person in their work. As the use of stakeholders is limited to human individuals, an interesting research question is whether the duty to stakeholder love can be extended to other stakeholders like associations composed of individuals, organizations, future generations, animals, and the natural environment (cf. Archer, 1997). More research on whether there is indeed no moral duty to love those stakeholders who are not dependent on one's decisions and those groups and individuals who have illegitimate interests is also relevant. It will also be interesting to explore how stakeholder love is related to self-love and whether self-love is a moral duty (cf. Maitland, 2002; Tangyin, 2008), when there is too much stakeholder love, how important the moral duty of stakeholder love is, whether there is a moral difference between loving a stakeholder composed of one person and loving a stakeholder composed of a group of individuals, and whether there are different types of stakeholder love (and likewise different levels of moral duty of stakeholder love). Other interesting research questions are on other possible arguments for the moral duty of stakeholder love, a corresponding stakeholder right to be loved (cf. Liao, 2012, 2015), and the duty of stakeholders to make themselves lovable. Such research can lead to an advanced moral theory of stakeholder love.

Another direction of research concerns the ethics resulting from stakeholder love. Once love is grounded as a moral duty, what does this mean for ethics? Does it imply specific duties and virtues? This question is partly addressed by the approach that focuses on the duties neighborly love entails. Love is not univocal. For example, Flescher (2000) shows that love can justify pacifism and war. Frankena (1973) advocates certain virtues based on an ethics of love. Van Dierendonck and Patterson (2015) also propose some virtues that servant leaders who have compassionate love should possess. Jordan et al. (2012) show that corporations that try to appear as a Good Samaritan but do not provide effective help (a Strategic Samaritan) receive more negative responses than corporations that do not claim to help. At the same time, we should be cautious in operationalizing love into virtues and behavioral norms. As mentioned above, it is characteristic of love that it is all-encompassing and not limited to certain dispositions and behavioral manifestations. However, an interesting research is whether we can define common elements of an ethics of stakeholder love.

Another research direction concerns the organizational duty of stakeholder love. This article operationalized the moral duty of stakeholder love at the individual level of workers as the subjects of love. An interesting question is whether organizations as moral entities can love their stakeholders and, if so, whether this too is a moral duty. Barsade and O'Neill (2014) already approached companionate love at the level of the culture of an organization. The organizational culture is an object for ascribing responsibilities to the organization as a moral entity (Kaptein \& Wempe, 2002), and Jones et al. (2007) have developed the concept of stakeholder culture. Hence, some building blocks are available for addressing the organizational duty of stakeholder love.

The concept of stakeholder love offers directions for descriptive and instrumental research. Because the concept of stakeholder love is new, the question is whether it can be operationalized to assess the extent to which it prevails in practice. There are some studies on love in the work setting, for instance Barsade and O'Neill (2014, 2016), but they all use limited operationalizations of neighborly love, like compassionate and companionate love, and restrict it to specific stakeholders, like clients and colleagues. If we could assess stakeholder love, for instance by learning from general measures of love like Fehr and Sprecher's (2008), we may be able to describe how stakeholder love varies, develops, and manifests itself. We may also discover the outcomes of stakeholder love and how important it is. For example, do the loved stakeholders feel attracted and attached (cf. 
Baumeister \& Leary, 1995), and do they act differently when they are not loved and from those who are not loved? For example, Bagley (2015) argues that lovers jointly engage in deep improvisation, and Caldwell and Dixon (2010) argue that when we are loved, we strengthen our self-esteem. Furthermore, Cignatto (2019) suggests that compassionate love has many positive outcomes, such as stronger cooperation with stakeholders, more community involvement, and better care of natural resources. A caution regarding instrumental research on stakeholder love needs to be mentioned here. Research that shows that stakeholder love is beneficial for those who exercise it should not be used to convince people to love their stakeholders because then we run the risk of stakeholder love being driven by own interests rather than by the stakeholder's interests. This would destroy the value of the concept of stakeholder love.

\section{Practical Implications}

The moral duty of stakeholder love has practical implications. Organizational boards should consider including the moral duty of stakeholder love in the organization's code of ethics. Some organizations, such as $\mathrm{CPH} \&$ Associates, Albéa, and Kuder, ${ }^{1}$ already state that they love their customers. But loving one's stakeholders is a much broader concept.

Organizations should also create a work environment to enable managers and employees to love their stakeholders. A code of ethics or wearing an I-Love-You button does not embed love in the heads and hearts of managers and employees. In much the same way that organizations are supposed to create a work environment where their managers and employees are stimulated to behave in an ethical way (Paine, 1994; Treviño \& Weaver, 2003), organizations should also create an environment that encourages the exercise of the moral duty to love one's stakeholders. Barsade and O'Neill (2014) point to the importance of the organizational culture in stimulating love, and Van Dierendonck and Patterson (2015) to the importance of leadership and role modeling. Organizations can also create a structure that stimulates stakeholder love. For example, Graber and Mitcham (2008) discuss how love in hospitals can be managed by reward systems and education. As closeness stimulates love (Brody et al., 2008), stakeholder love can be stimulated by encouraging managers and employees to have contact with stakeholders, organizing stakeholder dialogues, and informing managers and employees about the stakeholders, their relevant values and how these are affected by the decisions

\footnotetext{
1 The websites of these companies were visited on July 1, 2021: https://www.cphins.com/five-reasons-we-love-our-customers/; https:// www.albea-group.com/en-gb/we-love-our-customers; https://www. kuder.com/blog/general/five-reasons-we-love-our-clients/.
}

in the organization. An organization may also be built on stakeholder love. For example, we learn from Ip (2002) that love is at the heart of all corporate activities in the Weizhi Group and that the founder of Randstad suggested building the company on the concept of agape (Randstad, 2017).

A final practical implication of the moral duty of stakeholder love is that there are no practical implications, meaning, love cannot or at least should not be operationalized in detailed prescriptions for what to do in practice (cf. Fromm, 1956). The basic idea of love is that it is an affection. People in their work can and should cultivate this affection because this is what the moral duty of stakeholder love entails. Goethe (1836, p. 441) said, "Love can do much, but duty more." Hopefully the duty to love can do even more.

Open Access This article is licensed under a Creative Commons Attribution 4.0 International License, which permits use, sharing, adaptation, distribution and reproduction in any medium or format, as long as you give appropriate credit to the original author(s) and the source, provide a link to the Creative Commons licence, and indicate if changes were made. The images or other third party material in this article are included in the article's Creative Commons licence, unless indicated otherwise in a credit line to the material. If material is not included in the article's Creative Commons licence and your intended use is not permitted by statutory regulation or exceeds the permitted use, you will need to obtain permission directly from the copyright holder. To view a copy of this licence, visit http://creativecommons.org/licenses/by/4.0/.

\section{References}

Acevedo, A. (2012). Personalist business ethics and humanistic management: Insights from Jacques Maritain. Journal of Business Ethics, 105(2), 197-219.

Agle, B. R., Mitchell, R. K., \& Sonnenfeld, J. A. (1999). Who matters to CEOs? An investigation of stakeholder attributes and salience, corporate performance, and CEO values. Academy of Management Journal, 42(5), 507-525.

Agarwal, J., Stackhouse, M., \& Osiyevskyy, O. (2018). I love that company: Look how ethical, prominent, and efficacious it is-A triadic organizational reputation (TOR) scale. Journal of Business Ethics, 153(3), 889-910.

Agosta, L. (2020). Empathy and sympathy in ethics. Internet Encyclopedia of Philosophy.

Annas, J. (1984). Personal love and Kantian ethics in Effi Briest. Philosophy and Literature, 8(1), 15-31.

Applebaum, H. A. (1992). The concept of work: Ancient, medieval, and modern. SUNY Press.

Archer, J. (1997). Why do people love their pets? Evolution and Human Behavior, 18(4), 237-259.

Arendt, H. (1963/1991). On revolution. Penguin.

Aquinas, T. (1485/2000). The summa theologica. Ave Maria Press.

Argandoña, A. (2011). Beyond contracts: Love in firms. Journal of Business Ethics, 99(1), 77-85.

Augustine of Hippo. (400/1998). Confessions: A new translation by Henry Chadwick. Oxford University Press.

Badiou, A., \& Truong, N. (2012). In praise of love. New Press.

Bagley, B. (2015). Loving someone in particular. Ethics, 125(2), 477-507.

Baron, M. (1986). On admirable immorality. Ethics, 96(3), 557-566. 
Barsade, S. G., \& O'Neill, O. A. (2014). What's love got to do with it? A longitudinal study of the culture of companionate love and employee and client outcomes in a long-term care setting. Administrative Science Quarterly, 59(4), 551-598.

Barsade, S., \& O'Neill, O. A. (2016). Manage your emotional culture. Harvard Business Review, 94(1), 58-66.

Barth, K. (1936/2004). Church dogmatics: The doctrine of the Word of God. Bloomsbury Publishing.

Baumeister, R. F., \& Leary, M. R. (1995). The need to belong: Desire for interpersonal attachments as a fundamental human motivation. Psychological Bulletin, 117(3), 497-529.

Blatt, R. (2009). Tough love: How communal schemas and contracting practices build relational capital in entrepreneurial teams. Academy of Management Review, 34(3), 533-551.

Boyd, C. (2010). The debate over the prohibition of romance in the workplace. Journal of Business Ethics, 97(2), 325-338.

Bridoux, F., \& Stoelhorst, J. W. (2014). Microfoundations for stakeholder theory: Managing stakeholders with heterogeneous motives. Strategic Management Journal, 35(1), 107-125.

Brody, S., Wright, S. C., Aron, A., \& McLaughlin-Volpe, T. (2008). Compassionate love for individuals in other social groups. In B. Fehr, S. Sprecher, \& L. G. Underwood (Eds.), The science of compassionate love: Theory, research, and applications (pp. 283-308). Wiley.

Brough, A. R., \& Isaac, M. S. (2012). Finding a home for products we love: How buyer usage intent affects the pricing of used goods. Journal of Marketing, 76(4), 78-91.

Burton, B. K., \& Dunn, C. P. (1996). Feminist ethics as moral grounding for stakeholder theory. Business Ethics Quarterly, 6(2), 133-147.

Caldwell, C., \& Dixon, R. D. (2010). Love, forgiveness, and trust: Critical values of the modern leader. Journal of Business Ethics, 93(1), 91-101.

Carroll, B. A., \& Ahuvia, A. C. (2006). Some antecedents and outcomes of brand love. Marketing Letters, 17(2), 79-89.

Cavanaugh, L. A., Bettman, J. R., \& Luce, M. F. (2015). Feeling love and doing more for distant others: Specific positive emotions differentially affect prosocial consumption. Journal of Marketing Research, 52(5), 657-673.

Childs, J. M. (1997). Business in an age of downsizing. Business Ethics Quarterly, 7(2), 123-131.

Chua, R. Y. J., Ingram, P., \& Morris, M. W. (2008). From the head and the heart: Locating cognition-and affect-based trust in managers' professional networks. Academy of Management Journal, 51(3), 436-452.

Cignacco, B. R. (2019). The art of compassionate business: Main principles for the human-oriented enterprise. Routledge.

Cima, L. R., \& Schubeck, T. L. (2001). Self-interest, love, and economic justice: A dialogue between classical economic liberalism and catholic social teaching. Journal of Business Ethics, 30(3), 213-231.

Clough, W. R. (2006). To be loved and to love. Journal of Psychology and Theology, 34(1), 23-31.

Cooley, D. R. (2002). False friends. Journal of Business Ethics, 36(3), 195-206.

Cowden, M. (2012a). What's love got to do with it? Why a child does not have a right to be loved. Critical Review of International Social and Political Philosophy, 15(3), 325-345.

Cowden, M. (2012b). A need is not a right. Critical Review of International Social and Political Philosophy, 15(3), 359-362.

Dalman, M. D., Buche, M. W., \& Min, J. (2019). The differential influence of identification on ethical judgment: The role of brand love. Journal of Business Ethics, 158(3), 875-891.

Das Neves, J. C., \& Melé, D. (2013). Managing ethically cultural diversity: Learning from Thomas Aquinas. Journal of Business Ethics, 116(4), 769-780.
De George, R. T. (1986). Theological ethics and business ethics. Journal of Business Ethics, 5(6), 421-432.

Delaney, N. (1996). Romantic love and loving commitment: Articulating a modern ideal. American Philosophical Quarterly, 33(4), 339-356.

Descartes, R. (1649/2015). The passions of the soul and other late philosophical writings. Oxford World's Classics. Oxford University Press.

van Dierendonck, D., \& Patterson, K. (2015). Compassionate love as a cornerstone of servant leadership: An integration of previous theorizing and research. Journal of Business Ethics, 128(1), 119-131.

Dierksmeier, C. (2013). Kant on virtue. Journal of Business Ethics, 113(4), 597-609.

Donaldson, T., \& Preston, L. E. (1995). The stakeholder theory of the corporation: Concepts, evidence, and implications. Academy of Management Review, 20(1), 65-91.

Elley-Brown, M. J., \& Pringle, J. K. (2021). Sorge, Heideggerian ethic of care: Creating more caring organizations. Journal of Business Ethics, 168, 23-35.

Fehr, B., Sprecher, S., \& Underwood, L. G. (Eds.). (2008). The science of compassionate love: Theory, research, and applications. Wiley.

Ferracioli, L. (2014). The state's duty to ensure children are loved. Journal of Ethics \& Social Philosophy, 8(2), 1-19.

Ferris, R. (1988). How organizational love can improve leadership. Organizational Dynamics, 16(4), 41-51.

Ferry, L. (2013). On love: A philosophy for the twenty-first century. Wiley.

Flescher, A. (2000). Love and justice in Reinhold Neibuhr's prophetic Christian realism and Emmanuel Levinas's ethics of responsibility: Treading between pacifism and just-war theory. The Journal of Religion, 80(1), 61-82.

Fournier, S. (1998). Consumers and their brands: Developing relationship theory in consumer research. Journal of Consumer Research, 24(4), 343-373.

Frankena, W. K. (1973). The ethics of love conceived as an ethics of virtue. The Journal of Religious Ethics, 1(Fall), 21-36.

Frankfurt, H. G. (1998). Duty and love. Philosophical Explorations, $1(1), 4-9$.

Frankfurt, H. G. (1999). Necessity, volition, and love. Cambridge University Press.

Fredrickson, B. (2013). Love 2.0: How our supreme emotion affects everything we feel, think, do, and become. Avery.

Freeman, R. E. (1984/2010). Strategic management: A stakeholder approach. Cambridge University Press.

Freud, S. (1930/2014). Civilization and its discontents. Penguin.

Frierson, P. R. (2002). Learning to love: From egoism to generosity in Descartes. Journal of the History of Philosophy, 40(3), 313-338.

Fromm, E. (1956/2006). The art of loving. HarperCollins Publishing.

Fry, L. W. (2003). Toward a theory of spiritual leadership. The Leadership Quarterly, 14(6), 693-727.

von Goethe, J. W. (1836). Göthe's Sämmtliche Werke. Tétot Frères.

Graber, D. R., \& Mitcham, M. D. (2008). Compassionate clinicians: Exemplary care in hospital settings. In B. Fehr, S. Sprecher, \& L. G. Underwood (Eds.), The science of compassionate love: Theory, research, and applications (pp. 345-372). Wiley.

Hanley, R. P. (2017). Love's enlightenment: Rethinking charity in modernity. Cambridge University Press.

Hardt, M., \& Negri, A. A. (2004). Multitude: War and democracy in the age of empire. Penguin.

Harris, H. (2002). Is love a management virtue? Business \& Professional Ethics Journal, 21(3/4), 173-184.

Hegel, G. W. F. (1820/2017). Elements of the philosophy of right (A. W. Wood, Ed.). Cambridge University Press.

Heidegger, M. (1927/2011). Being and time. Harper and Row. 
Helm, B. W. (2010). Love, friendship, and the self: Intimacy, identification, and the social nature of persons. Oxford University Press.

Helm, B. (2017). Love. In: E. N. Zalta (Ed.), The stanford encyclopedia of philosophy. https://plato.stanford.edu.

Hendrick, S., \& Hendrick, C. (1992). Liking, loving and relating. Brooks/Cole.

Hobbes, T. (1651/2009). Leviathan. BiblioLife.

Horn, C. (2008). The concept of love in Kant's virtue ethics. In M. Betzler (Ed.), Kant's Doctrine of virtue (pp. 147-173). Walter de Gruyter.

Hosmer, L. T., \& Kiewitz, C. (2005). Organizational justice: A behavioral science concept with critical implications for business ethics and stakeholder theory. Business Ethics Quarterly, 15(1), 67-91.

Ip, P. K. (2002). The Weizhi group of Xian: A Chinese virtuous corporation. Journal of Business Ethics, 35(1), 15-26.

Jones, T. M., \& Wicks, A. C. (1999). Convergent stakeholder theory. Academy of Management Review, 24(2), 206-221.

Jones, T. M., Felps, W., \& Bigley, G. A. (2007). Ethical theory and stakeholder-related decisions: The role of stakeholder culture. Academy of Management Review, 32(1), 137-155

Jordan, J., Diermeier, D. A., \& Galinsky, A. D. (2012). The strategic Samaritan: How effectiveness and proximity affect corporate responses to external crises. Business Ethics Quarterly, 22(4), 621-648.

Kant, I. (1797/2017). The metaphysics of morals. Cambridge texts in the history of philosophy (M. Gregor, \& J. Timmermann, Eds.). Cambridge University Press.

Kaptein, M., \& Wempe, J. F. D. B. (2002). The balanced company: A theory of corporate integrity. Oxford University Press.

Kapur, N. B. (1991). Why it is wrong to be always guided by the best: Consequentialism and friendship. Ethics, 101(3), 483-504.

Karakas, F. (2010). Spirituality and performance in organizations: A literature review. Journal of Business Ethics, 94(1), 89-106.

Kaufmann, J. C. (2011). The curious history of love. Polity Press.

Kidder, J. L. (2006). "It's the job that I love": Bike messengers and Edgework. Sociological Forum, 21(1), 31-54.

Kierkegaard, S. (1847/2013). Works of love. Princeton University Press.

Klein, S. (2002). The head, the heart, and business virtues. Journal of Business Ethics, 39(4), 347-359.

Koehn, D. (1998). Can and should businesses be friends with one another and with their stakeholders. Journal of Business Ethics, 17(15), 1755-1763.

Kouzes, J. M., \& Posner, B. Z. (1992). Ethical leaders: An essay about being in love. Journal of Business Ethics, 11(5-6), 479-484.

Kuhn, J. W. (1992). Ethics in business: What managers practice that economists ignore. Business Ethics Quarterly, 2(3), 305-315.

La Caze, M. (2005). Love, that indispensable supplement: Irigaray and Kant on love and respect. Hypatia, 20(3), 92-114.

Laplume, A. O., Sonpar, K., \& Litz, R. A. (2008). Stakeholder theory: Reviewing a theory that moves us. Journal of Management, 34(6), 1152-1189.

Lee, J. A. (1977). A typology of styles of loving. Personality and Social Psychology Bulletin, 3(2), 173-182.

Leibniz, G. W. (1693/2011). Philosophical papers and letters (L. E. Loemker, Ed.). Literary Licensing.

Levinas, E., \& Robbins, J. (2001). Is it righteous to be? Interviews with Emmanuel Levinas. Stanford University Press.

Lewis, C. S. (1960/1991). The four loves. Harcourt Books.

Liao, S. M. (2006). The idea of a duty to love. The Journal of Value Inquiry, 40(1), 1-22.

Liao, S. M. (2012). Why children need to be loved. Critical Review of International Social and Political Philosophy, 15(3), 347-358.

Liao, S. M. (2015). The right to be loved. Oxford University Press.

Liedtka, J. M. (1996). Feminist morality and competitive reality: A role for an ethic of care? Business Ethics Quarterly, 6(2), 179-200.
Longenecker, P. D. (2013). The positive impact of individual core values. Journal of Business Ethics, 115(3), 429-434.

Luther, M. (1520/2018). A treatise on Christian liberty: On the freedom of a Christian. Fortress Press.

Mackie, J. (1990). Ethics: Inventing right and wrong. Penguin.

Maitland, I. (2002). The human face of self-interest. Journal of Business Ethics, 38(1-2), 3-17.

Majerhold, K. (2020). History of love. Internet Encyclopedia of Philosophy. https://www.iep.utm.edu.

Martin, M. W. (1993). Love's constancy. Philosophy, 68(263), 63-77.

Mayer, R. C., Davis, J. H., \& Schoorman, F. D. (1995). An integrative model of organizational trust. Academy of Management Review, 20(3), 709-734.

Melé, D. (2009). Integrating personalism into virtue-based business ethics: The personalist and the common good principles. Journal of Business Ethics, 88(1), 227-244.

Melé, D., \& Naughton, M. (2011). The encyclical-letter "Caritas in Veritate": Ethical challenges for business. Journal of Business Ethics, 100(1), 1-7.

McCann, D. (2011). The principle of gratuitousness: Opportunities and challenges for business in «Caritas in Veritate». Journal of Business Ethics, 100(1), 55-66.

Mitchell, R. K., Agle, B. R., \& Wood, D. J. (1997). Toward a theory of stakeholder identification and salience: Defining the principle of who and what really counts. Academy of Management Review, 22(4), 853-886.

Moore, D. (2018). Reconciling appraisal love and bestowal love. Dialogue: Canadian Philosophical Review, 57(1), 67-92.

Natoli, G. (2008). Augustinian moral consciousness and the businessman. Journal of Business Ethics, 78(1-2), 97-107.

Neusner, J., \& Chilton, B. (Eds.). (2005). Altruism in world religions. Georgetown University Press.

Nozick, R. (1989). The examined life: Philosophical meditations. Simon \& Schuster.

Nussbaum, M. C. (2013). Political emotions: Why love matters for justice. The Belknap Press of Harvard University Press.

Nygren, A. (1930/1953). Agape and eros. Harper \& Row.

O'Neill, O. A., \& Rothbard, N. P. (2017). Is love all you need? The effects of emotional culture, suppression, and work-family conflict on firefighter risk-taking and health. Academy of Management Journal, 60(1), 78-108.

Okpala, C., \& Caldwell, C. (2019). Humility, forgiveness, and love: The heart of ethical stewardship. The Journal of Values-Based Leadership, 12(2), 10

Oord, T. J. (2010). The nature of love: A theology. Chalice Press.

Paine, L. S. (1994). Managing for organizational integrity. Harvard Business Review, 72(2), 106-117.

Parmar, B. L., Freeman, R. E., Harrison, J. S., Wicks, A. C., Purnell, L., \& De Colle, S. (2010). Stakeholder theory: The state of the art. The Academy of Management Annals, 4(1), 403-445.

Phillips, R. (2003). Stakeholder legitimacy. Business Ethics Quarterly, 13(1), 25-41.

Post, S. G., Underwood, L. G., Schloss, J. P., \& Hurlbut, W. B. (2002). Altruism and altruistic love: Science, philosophy, and religion in dialogue. Oxford University Press.

Randstad. (2017). The best job in the world: The ideas and practice of Frits Goldschmeding, founder of Randstad. NPN Drukkers.

Raz, J. (1994). Ethics in the public domain: Essays in the morality of law and politics. Clarendon.

Reis, H. T., \& Aron, A. (2008). Love: What is it, why does it matter, and how does it operate? Perspectives on Psychological Science, $3(1), 80-86$.

Rinne, P. (2018). Kant on love. Walter de Gruyter.

Rothausen, T. J. (2017). Integrating leadership development with Ignatian spirituality: A model for designing a spiritual leader development practice. Journal of Business Ethics, 145(4), 811-829. 
Ruhe, J., \& Lee, M. (2008). Teaching ethics in international business courses: The impacts of religions. Journal of Teaching in International Business, 19(4), 362-388.

Tang, T. L. P., Sutarso, T., Davis, G. M. T. W., Dolinski, D., Ibrahim, A. H. S., \& Wagner, S. L. (2008). To help or not to help? The Good Samaritan Effect and the love of money on helping behavior. Journal of Business Ethics, 82(4), 865-887.

Tangyin, K. (2008). Reading Levinas on ethical responsibility. In: Kwan, T., Responsibility and commitment: Eighteen essays in honor of Gerhold K. Becker (pp. 155-172).

Tasselli, S. (2019). Love and organization studies: Moving beyond the perspective of avoidance. Organization Studies, 40(7), 1073-1088.

Taylor, R. (1970). Good and evil: A forceful attack on the rationalistic tradition in ethics. Macmillan.

Templeton, J. (1999). Agape love: A tradition found in eight world religions. Templeton Foundation Press.

Treviño, L. K., \& Weaver, G. R. (2003). Managing ethics in business organizations: Social scientific perspective. Stanford University Press.

Sandelands, L. (2009). The business of business is the human person: Lessons from the Catholic social tradition. Journal of Business Ethics, 85(1), 93-101.

Sandelands, L. E. (2017). The real mystery of positive business: A response from Christian faith. Journal of Business Ethics, 145(4), 771-780.

Schönecker, D., Cotter, A., Eckes, M., \& Maly, S. (2010). Kant über Menschenliebe als moralische Gemütsanlage. Archiv für Geschichte der Philosophie, 92(2), 133-175.

Schopenhauer, A. (1840/2005). The basis of morality. Dover Publications.

Singer, I. (2009). Nature of love. MIT Press.

Solheim, B. P. (1999). The possibility of a duty to love. Journal of Social Philosophy, 30(1), 1-17.

Solomon, R. C. (1998). The moral psychology of business: Care and compassion in the corporation. Business Ethics Quarterly, 8(3), $515-533$.

Sternberg, R. J. (1986). A triangular theory of love. Psychological Review, 93(2), 119-135.

Strangleman, T., \& Warren, T. (2008). Work and society: Sociological approaches, themes and methods. Routledge.

Underwood, L. G. (2008). Compassionate love: A framework for research. In B. Fehr, S. Sprecher, \& L. G. Underwood (Eds.),
The science of compassionate love: Theory, research, and applications (pp. 3-26). Wiley.

Vacek, E. C. (1994). Love, human and divine: The heart of Christian ethics. Georgetown University Press.

Velleman, J. D. (1999). Love as a moral emotion. Ethics, 109(2), $338-374$.

Voice, P. (2011). The authority of love as sentimental contract. Essays in Philosophy, 12(1), 93-111.

Wallace, R. J. (2012). I-Duties of love. Aristotelian Society Supplementary, 86(1), 175-198.

Wennemann, D. J. (1998). The role of love in the thought of Kant and Kierkegaard. The Paideia Archive: Twentieth World Congress of Philosophy, 36, 219-224.

Whiting, J. E. (1991). Impersonal friends. The Monist, 74(1), 3-29.

Wicks, A. C., Gilbert, D. R., Jr., \& Freeman, R. E. (1994). A feminist reinterpretation of the stakeholder concept. Business Ethics Quarterly, 4(4), 475-497.

Williams, O. (1986). Can business ethics be theological. The Journal of Business Ethics, 5(6), 473-484.

Wolf, S. (1992). Morality and partiality. Philosophical Perspectives, 6, 243-259.

Yim, C. K., Tse, D. K., \& Chan, K. W. (2008). Strengthening customer loyalty through intimacy and passion: Roles of customer-firm affection and customer-staff relationships in services. Journal of Marketing Research, 45(6), 741-756.

Yuengert, A. (2011). Economics and interdisciplinary exchange in Catholic social teaching and "Caritas in Veritate." Journal of Business Ethics, 100(1), 41-54.

Zeiher, C. (2017). Struggle as love par excellence: Zupančič avec Badiou. In C. Zeiher \& T. McGowan (Eds.), Can philosophy love? Reflections and encounters (pp. 297-310). Rowman \& Littlefield.

Zeiher, C., \& McGowan, T. (2017). Can philosophy love? Reflections and encounters. Rowman \& Littlefield.

Publisher's Note Springer Nature remains neutral with regard to jurisdictional claims in published maps and institutional affiliations. 